\title{
A területi kormányzás és a területi integráció vizsgálata Baranya megye fejlesztési dokumentumaiban az uniós csatlakozástól napjainkig
}

\section{Overview of territorial governance and territorial integration in development documents of Baranya county, since the EU accession to date}

\section{PÁMER ZOLTÁN}

PÁMER Zoltán: tudományos munkatárs, Közgazdaság- és Regionális Tudományi Kutatóközpont, Regionális Kutatások Intézete; 7621 Pécs, Papnövelde u. 22.; pamer.zoltan@krtk.hu; https://orcid.org/0000-0002-5046-9590

KULCSSZAVAK: területi kormányzás; területi tervezés; helyalapú fejlesztés; kohéziós politika; Baranya megye

ABSZTRAKT: A magyar területfejlesztési politika origójának tekinthető 1996-os területfejlesztési törvény elfogadásakor szervesen illeszkedett az európai területi gondolkodást meghatározó folyamatokba. Az európai területi gondolkodás, a kohéziós politika újabb időszakaiban megjelenő logika, a területi kohézió és területi integráció kérdése, az új eszközök lenyomata azonban már csak részben, vagy egyáltalán nem jelent meg a szabályozásban. A tanulmány célja, hogy Baranya megye példáján bemutassa a magyar területfejlesztési politika korszakait az uniós csatlakozást megelőző évtől napjainkig, mindezt a helyalapú (placebased) területfejlesztési politikai megközelítés érvényesülésén keresztül.

A tanulmány első része áttekintő jelleggel bemutatja a területi kormányzás és a területi kohézió fogalmainak szakirodalmi hátterét, annak jelentőségét az európai integrációs folyamatban, valamint a kohéziós politika szabályozásában, kiemelve a helyalapú szemlélet alkalmazását. A tanulmány második felében, rövid módszertani összefoglalót követően, a Baranya megye esetében meghatározó fejlesztési koncepciók és programok összehasonlító elemzése következik a Fabrizio Barca által vezetett kutatócsoport által kidolgozott jelentésben alkalmazott place-based tipológia alapján. Az alkalmazott kvalitatív elemzés három dimenziója a tervezési folyamatra jellemző dialógus és részvétel; a területi diverzitás és tudás jelenléte a dokumentumokban; illetve a valóságos kapacitással rendelkező területi intézmények megléte. A módszer segítségével kimutathatók a három jól behatárolható korszak hasonlóságai és különbségei, az egyes kritériumok esetében érzékelhető tendenciák, melyek javaslatok megfogalmazására is lehetőséget adnak.

Zoltán PÁMER: research fellow, Institute for Regional Studies, Centre for Economic and Regional Studies; Papnövelde u. 22., H- 7621 Pécs, Hungary; pamer.zoltan@krtk.hu; https://orcid.org/00000002-5046-9590

KEYWORDS: territorial governance; territorial planning; place-based approach; cohesion policy; Baranya county

ABSTRACT: The Regional Development Act of Hungary in 1996 was part of the European mainstream. However, in subsequent periods, the European discourse on territoriality, the placebased approach of European cohesion policy, notions of 'territorial cohesion' and 'territorial

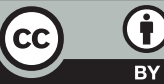


integration' have only partially been integrated into national regulations. The aim of this study is to highlight the distinctive periods of Hungarian regional development policy through the example of Baranya county and manifestations of the place-based approach between 2003 and the present.

The first part of the study provides a theoretical overview on territorial governance, territorial cohesion, and their significance in the European integration process. This section also outlines regulations of $E U$ cohesion policy, its growing preference for tools of territorial integration and the place-based approach. This is followed by a short methodological summary and a subsequent comparative analysis of the relevant regional development documents (Baranya county development concept - 2003, South Transdanubian Operational Programme 2007-2013, Baranya county development concept and programme and the Baranya county integrated territorial programme of 2014-2020) that apply the place-based typology developed by Fabrizio Barca (2009). The three dimensions of the qualitative analysis include territorial dialogue, participation in the planning process; presence of territorial diversity and knowledge in documents; and the availability of regional institutions with real capacities.

As the analysis shows, dialogue and participation have been more and more regulated, thus ensured. While the Regional Development Act defined a narrow group of compulsory stakeholders to consult, later regulations expected deeper involvement and, more recent programmes, the preparation of partnership plans. Besides bottom-up procedures, top-down coordination has also been significantly strengthened in each period. Territorial diversity and the application of territorial knowledge have been investigated through the appearance of territorial objectives in documents. These were found to be available in each period, although with significantly different logics. The development programme of 2003 was an aggregation of microregional programmes, while the one in 2007 provided a differentiated territorial approach to each priority of a regional, yet centrally coordinated operational programme. The concept and programme of 2014 had a strong territorial approach, however the integrated territorial programme (ITP) of Baranya county promoted territoriality only through region-specific project selection criteria that was significantly different from the integrated territorial investment (ITI) tool introduced by the EU. In terms of the institutional criterion, the weaknesses identified in the 2003 document were somewhat remedied at the regional level in 2007. Nevertheless, the change in the role of county administrations led to the weakening of regional capacities for the 2014-2020 period. As a conclusion I suggest that the weak institutional framework has remained the key obstacle for place-based regional development policy in Hungary.

\section{Bevezető: területi kormányzás és területi kohézió}

A területi kormányzás (territorial governance) nem rendelkezik egyértelmü definícióval, számos meghatározása ismert. Stead alapján, aki a kormányzás fogalmi értelmezését vizsgálta, „meghatározott értékek és érdekek mentén történő koordinált cselekvésről” beszélhetünk (Stead 2014). A területi kormányzással kapcsolatos diskurzus előtérbe kerülése az „új regionalizmus” (Keating 1998) megjelenésétől datálható, mely egyértelműen összefügg az európai szakpolitikák - mindenekelőtt a kohéziós politika - régiókat előnyben részesítő fejlődésével. A területi alapú cselekvés azonban - az adott ország területi igazgatási berendezkedését figyelembe véve - megkívánhatja az adott területen kívüli szereplők részvételét is, ezáltal a sikeres területi kormányzás területen kívüli aktorok részvételétől is függ. Hooghe és Marks (2003) nagyhatású tanulmányában a területhez kötődő kormányzási megoldásokat I-es típusú (Type I) kormányzásnak, míg egy adott ügyhöz, feladathoz (task) kapcsolódót II-es típusú (Type II) kormányzásnak tekinti. Mindkét esetben a 
partnerség és szubszidiaritás elve mentén történő, a politikában részt vevő szereplők közötti hagyományos viszonyok fellazítására van szükség (Pálné Kovács 2009). A területi kormányzás vonatkozásában fontos kiemelni annak identitásképző jellegét: a területi szinten elért politikai sikerek egyben a helyi/regionális elit legitimációs bázisát is jelentik (Scott 2013).

Az 1992-ben aláírt, az Európai Unió létrehozásáról szóló maastrichti szerződés jelentősége a területi kormányzás előmozdítása szempontjából is kiemelkedő, mely a szubszidiaritás elvének szerződésbe való beemelésében jelenik meg (EP 2018), ez azonban két irányban is értelmezhető. Egyrészt kizárja az Európai Unió beavatkozását olyan területeken, melyek alacsonyabb szinteken (állami, regionális) hatékonyabban elláthatók (competence creep), másfelől biztosítékot jelent a szubnacionális szint bevonására, a decentralizált döntéshozatal előnyben részesítésére (Faludi 2013). Az Amszterdami Szerződés a gazdasági és társadalmi kohézió mellett bevezeti a területi kohézió fogalmát is, amit az új kohéziós fogalom mibenlétéről szóló intenzív vita követett (Manzella, Mendez 2009). Többen az európai szociális modell „területiesítésének” tekintették (Davoudi 2005), melynek eredményeként mint szakminiszteri állásfoglalás megszületett az Európai Területfejlesztési Perspektíva (European Spatial Development Perspective - ESDP 1999), amely amellett, hogy a területiség jelentőségét hangsúlyozza, az európai régiók közötti funkcionális kapcsolatok koordinációját kívánja elősegíteni (Faludi 2013). Először a Lisszaboni Szerződésben (2007) jelenik meg a 'governance' fogalma, melyet az Unió saját szerveinek működésére és a civil társadalom bevonására alkalmaz (Janin Rivolin 2010). Lisszabon ugyanakkor alapszerződési szinten területi dimenzióval ruházta fel a gazdasági és társadalmi kohéziót (Manzella, Mendez 2009).

Az integrált területi megközelítés előtérbe kerülése szempontjából fontos mérföldkő a 2007-es német uniós elnökség alatt megszülető Lipcsei Charta, mely a fenntartható európai városfejlesztés megvalósítása érdekében az integrált városfejlesztés eszközeinek alkalmazását szorgalmazza (EU2007.de 2007). Az integrált megközelítés a gazdasági, társadalmi, környezeti problémák együttes kezelését, illetve a különböző területi szintek együttműködését tette szükségessé (Barta 2009). Ezen megközelítés jegyében kezdődött meg az integrált városfejlesztési koncepciók kidolgozása.

A területi kohézióval kapcsolatos diskurzus újraindítását célozta a területi kohézióról szóló zöld könyv (Green Paper on Territorial Cohesion), mely szerint a területi kohézió a kohéziós politika továbbfejlesztését, annak rugalmasabbá tételét, a megfelelő területi szintekhez, helyi igényekhez való igazítását, a többi szakpolitikával való összehangolását szolgálja a szubszidiaritás elvével összhangban (EC 2008). A 2009-es svéd elnökség alatt Kirunában szervezett konferenciára készült vitaanyag kiemelten és általában, a városoktól függetlenül említi az integrált megközelítés szükségességét, integrált területi projektek kialakítását a helyi lehetőségek kihasználása érdekében (EC 2009). 
Az integrált területi megközelítés kohéziós politikába való szerves átültetésében kiemelkedő szerepet játszott a kohéziós politika reformjának előkészítését szolgáló 2009-es Barca-jelentés, mely az átfogó költségvetési reform mellett síkra száll a helyi adottságokhoz illeszkedő (place-based) szolgáltatások mellett, mind gazdasági, mind szociális szempontból. Ehhez, egy átfogó reformot követően, megfelelő eszköznek tartja a kohéziós politikát (Barca 2009). A jelentés megszületését megelőzően a közgazdasági gondolkodásban is egyre erősebbé vált a területalapú megközelítés, elvetve a „területileg vak” politikai szemléletet, elötérbe helyezve a városok és régiók növekedésben betöltött szerepét, az „új gazdaságföldrajz" megjelenését, illetve a helyi vállalkozások innovációs szerepét stb. (Beer et al. 2020). Barca arra hívja fel a figyelmet, hogy nem lehet elhanyagolni a térbeliséget: a helyi adottságok figyelembevétele magasabb költségekkel, ugyanakkor kisebb kockázatokkal jár, mint a felülről vezérelt megoldások. Barca a place-based megközelítéssel a fejlesztéspolitikát a hatékonysági és méltányossági szempontok metszetébe helyezi (Kovács 2013). A dokumentum a kormányzást nem jogi kérdésnek tekinti, hanem feladatoktól függő kormányzati megoldások kidolgozásaként kezeli. A dokumentum a területi integráltság kritériumait is meghatározza:

- Területi fókuszú, hosszú távú fejlesztési stratégia, mely azt célozza, hogy megszüntesse hatékonyság hiányát és az egyenlőtlenségeket az erőforrások kiaknázásában.

- Integrált, területileg beágyazott közjavak, szolgáltatások, melyeket a helyi preferenciák és tudás alapján, participatív (bevonáson alapuló) intézményeken keresztül kezelnek, más területek hasonló szerveivel együttműködésben.

- Mindezt kívülről egy többszintű kormányzási rendszer támogatja, mely meghatározott célok és feltételek mellett nyújt támogatásokat (Barca 2009, 5.).

Ennek értelmében a sikeres területi alapú megközelítés a belső (endogén) és külső (exogén) erőforrások kombinációjával alakítható ki, érvényesítéséhez pedig a fejlesztésben részt vevő aktorok közötti párbeszédre, területi szempontokat magában foglaló tudásra, illetve megfelelö, területileg beágyazott intézményekre van szükség (Ministry of Regional Development 2013).

\section{A területi integráció eszközeinek megjelenése a kohéziós politika szabályozásában}

Az 'integrált' kifejezés a korábbi programozási időszakokra vonatkozó szabályozásokban sem volt ismeretlen, a 'területileg integrált' megfogalmazás megjelenésére azonban egészen a 2014-ben induló programozási időszakig várni kellett.

A 2000-2006 közötti programozási időszakban, ellentétben a korábbi időszakok 'monofund' (egy operatív program egy alapból való finanszírozása) szemlélete 
helyett megjelent a komplex, több alapból finanszírozható programok lehetősége. Ezt nevezte az általános rendelet 'integrált' operatív programnak (Regulation 1999). A következő, 2007-2013-as programozási időszak szabályozásában az integrált megközelítés két vonatkozásban jelenik meg. Az európai területi együttműködés (korábban INTERREG közösségi kezdeményezés) besorolása a kohéziós politika fó célterületei közé a jellemzően elmaradott, vagy sajátos helyzetükből adódóan speciális megközelítést igénylő határtérségek fejlesztését igyekszik szolgálni integrált módon, a fóáramú és határon átnyúló együttmüködési programok egymáshoz illesztett kidolgozásával (Regulation 2006, 3. cikk, 2. c). Ugyanakkor a pénzügyi eszközök (visszatérítendő támogatások) igénybevételéhez az integrált fenntartható városfejlesztési tervek kidolgozását szabja feltételül (Regulation, 006, 44. cikk).

A globalizációval járó komplex gazdasági-társadalmi kihívások szükségessé teszik az integrált megközelítést. Az új időszakra aktuálisan kialakított tizenegy elemű célrendszer egyes elemei közötti átjárást lehetővé tevő megközelítés, a funkcionális térségek felé terelt figyelem, a makroregionális stratégiák kialakítása egyaránt az integrált megközelítés kiterjesztését sejteti. A partnerségi megállapodásoknak a speciális igényekkel rendelkező területek esetében integrált megközelítést kell alkalmazniuk (Regulation 2013, 14. cikk), mely kifejeződik az egyes pénzügyi alapok, a területi lehatárolás rugalmas értelmezésében, a közösségi bevonás szükségességében, illetve az egyes területi szinteken működő szakpolitikák kombinációjában. Az általános elvárásként megfogalmazott integrált megközelítés mellett két új, célzott integrált területi eszköz került bevezetésre:

- A közösség-vezérelt helyi fejlesztések (community-led local development - CLLD) a korábbi időszakból ismert, helyi akciócsoportok által végrehajtott LEADER programok szemléletét igyekszik általánossá tenni, a kisközösségek fejlesztését célozza, integrálva a különböző finanszírozási eszközöket (Regulation 2013, 32. cikk).

- Az integrált területi beruházás (integrated territorial investment - ITI) kifejezetten a nagyvárosokat célozza funkcionális várostérségekként, multifund-alapú (pl. Európai Regionális Fejlesztési Alap - ERFA, Európai Szociális Alap - ESZA), területi fókuszú, az adminisztratív határokat rugalmasan kezelő megközelítéssel (Regulation 2013, 36. cikk).

\section{A vizsgálat során alkalmazott módszerek}

A helyalapú megközelítést a magyar területfejlesztési politikában a Baranya megyei területfejlesztési dokumentumok kvalitatív elemzésén keresztül szándékozom bemutatni. Baranya megye egyfelől ideális példa (mind területe, mind népessége szempontjából átlagos méretủ megyének számít), ugyanakkor Baranya az egyik leginkább leszakadó pályával jellemezhető megye is Magyarországon. 
Tanulmányomnak nem célja Baranya relatív hanyatlása okainak feltárása; a megyei dokumentumok elemzése példaként szolgál a magyar helyalapú területpolitikai megközelítés hiányosságainak megvilágítására.

A területfejlesztésről és -rendezésről szóló 1996-ban elfogadott törvény (Tft.) számos koncepcionális és apróbb, technikai módosításon ment keresztül az elmúlt közel 25 évben. A jogszabály fó célja, a területi különbségek csökkentése valamennyi változatban megjelent, a cél elérésének módjában, kiemelten a decentralizáció és centralizáció kérdésében azonban erős ciklikusság figyelhető meg (Pálné Kovács, Mezei 2016). A területfejlesztési törvény mellett változó jogi környezet jellemezte a tervezésben, programozásban való részvétel folyamatát is, amelyeket különböző szintű jogszabályok fektettek le.

A dokumentumok vizsgálatakor a Barca-jelentés (2009) által meghatározott kritériumok mentén a lengyel területfejlesztési minisztérium koordinációjával (Ministry of Regional Development 2013) végzett, európai léptékü empirikus vizsgálat során alkalmazott módszertant vettem figyelembe. A kutatás során a Baranya megye szempontjából jelentős megyei vagy regionális fejlesztési dokumentumokat tekintettem át a dokumentumelemzés módszerével, illetve, kiegészítő jelleggel, félig strukturált interjúkat készítettem. (A vizsgált szempontokat az 1. táblázat mutatja).

1. táblázat: A kvalitatív kutatás során alkalmazott módszertan The applied methodology of the qualitative analysis

\begin{tabular}{|c|c|c|c|}
\hline & Szempont & Kritérium & Dokumentumelemzés módszere \\
\hline 1 & $\begin{array}{l}\text { Területi dialógus és bevo- } \\
\text { nás: valós, többszintű dia- } \\
\text { lógus a fejlesztési folyamat- } \\
\text { ban részt vevő szervezetek } \\
\text { között. }\end{array}$ & $\begin{array}{l}\text { A kidolgozásban részt vevő } \\
\text { szintek (helyi, regionális, } \\
\text { állami) száma, a top-down és } \\
\text { bottom-up koordináció } \\
\text { jellege. }\end{array}$ & $\begin{array}{l}\text { A jogi háttér és szakiroda- } \\
\text { lom áttekintésén, interjúk } \\
\text { készítésén keresztül a dön- } \\
\text { téshozatali folyamat rekon- } \\
\text { strukciója, az egyes területi } \\
\text { szintek szerepének feltárá- } \\
\text { sa. }\end{array}$ \\
\hline 2 & $\begin{array}{l}\text { Területi diverzitás és tudás: } \\
\text { területi diverzitás elismeré- } \\
\text { se a fejlesztési célok megfo- } \\
\text { galmazásában. }\end{array}$ & $\begin{array}{l}\text { Egy vagy több területi cél, } \\
\text { vagy területi preferenciák } \\
\text { megléte a dokumentumban. }\end{array}$ & $\begin{array}{l}\text { A dokumentumban megha- } \\
\text { tározott átfogó és specifikus } \\
\text { célok, prioritások és beavat- } \\
\text { kozások területi logika sze- } \\
\text { rinti áttekintése. }\end{array}$ \\
\hline 3 & $\begin{array}{l}\text { Területi intézmények: } \\
\text { valóságos intézményi háttér } \\
\text { megléte. }\end{array}$ & $\begin{array}{l}\text { A dokumentumban címzett } \\
\text { szervezetek valós mandá- } \\
\text { tummal és kapacitással } \\
\text { rendelkeznek a megfogal- } \\
\text { mazott célok eléréséhez, } \\
\text { avagy azok elérésének } \\
\text { elősegítéséhez. }\end{array}$ & $\begin{array}{l}\text { A végrehajtás intézmény- } \\
\text { rendszerének áttekintése a } \\
\text { jogi háttér, szakirodalom } \\
\text { ismeretében, interjúk } \\
\text { készítésén keresztül. }\end{array}$ \\
\hline
\end{tabular}


A vizsgálat az uniós csatlakozás (2004) óta hatályos Baranya megyei fejlesztési koncepciókra és programokra terjedt ki, melyek a Tft.-vel összhangban készültek. Mivel a 2003-ban készült megyei programot a 2007-2013-as időszakban nem követte egy újabb megyei koncepció és/vagy program, az időszak meghatározó szubnacionális fejlesztési programját, a kohéziós politika végrehajtását szolgáló, így a Tft. kompetenciáján kívül eső Dél-Dunántúli Operatív Programot (DDOP) is bevontam az elemzésbe. 2014-ben ismét készült a Tft.-vel összhangban megyei koncepció és program, a kohéziós politikai kapcsolat bemutatása érdekében azonban kitérek a 2015-ös megyei Integrált Területi Programra (ITP) is (2. táblázat).

2. táblázat: A vizsgált dokumentumok köre és típusai The array and typology of analysed documents

\begin{tabular}{|c|c|c|}
\hline Dokumentum címe & Típusa & Szabályozási háttér \\
\hline $\begin{array}{c}\text { Baranya megye területfejlesz- } \\
\text { tési programja } 2003\end{array}$ & Megyei program & Területfejlesztési törvény \\
\hline $\begin{array}{l}\text { Dél-Dunántúli Operatív Prog- } \\
\text { ram (DDOP) 2007-2013 }\end{array}$ & Regionális operatív program & $\begin{array}{c}\text { Kohéziós politika - Nemzeti } \\
\text { Stratégiai Referenciakeret } \\
\text { 2007-2013 }\end{array}$ \\
\hline $\begin{array}{l}\text { Baranya Megyei Területfejlesz- } \\
\text { tési Koncepció 2014-2020 }\end{array}$ & Megyei koncepció & Területfejlesztési törvény \\
\hline $\begin{array}{l}\text { Baranya Megyei Területfejlesz- } \\
\text { tési Program 2014-2020 }\end{array}$ & Megyei program & Területfejlesztési törvény \\
\hline Baranya Megye Integrált & Megyei integrált területi & Kohéziós politika - Partnerség \\
\hline Területi Programja 2015-2020 & program & Megállapodás \\
\hline
\end{tabular}

Forrás: saját szerkesztés

A dokumentumelemzést kiegészítendő, összesen négy félig strukturált interjút készítettem olyan szakemberekkel, akik különböző időszakokban a Baranya Megyei Önkormányzatnál a területfejlesztési feladatok koordinációjának felelősei voltak (területfejlesztési irodavezető, területfejlesztési osztályvezető, vezető területfejlesztési koordinátor). Az interjúk során a különböző fejlesztési dokumentumok kapcsán a következő kérdésköröket jártam körül:

- A program kidolgozásának menete: kik készítették a programot? Mi volt a bevonás folyamata, a szabályozási háttér?

- Területi diverzitás a dokumentumban: milyen volt a tematikus és területi célok viszonya? Milyen módszer szerint határozták meg a területi célokat?

- Intézményi kérdések: a megye koordinatív szerepe miben jelenik meg? Voltak-e a megyének saját végrehajtású projektjei? Milyen intézményi fejlesztéseket eredményezett a program végrehajtása? Melyek voltak a fó végrehajtó intézmények (nem csak a közreműködő szervezetek)? 
Az egyes interjúalanyok jellemzően nem tudtak valamennyi kérdésre maradéktalanul válaszolni, mivel néhány megkérdezett szereplő csak rövid ideig töltötte be a funkciót, jelentős volt a fluktuáció. Az interjúkról hangfeltétel nem, csak írásbeli jegyzet készült, melyre a tanulmányban több helyütt, név nélkül hivatkozom.

\section{Megyei fejlesztéspolitika az uniós csatlakozás idején}

A megyei területfejlesztési tanács, a Tft. értelmében a megye területfejlesztési kérdésekben felelős testületeként 2003 szeptemberében fogadta el Baranya Megye Területfejlesztési Programját. A megyei területfejlesztési tanácsot a Tft. hozta létre, a megyei önkormányzattal párhuzamosan működött, megyei, helyi önkormányzati és kormányzati delegáltakból állt. A tervezési folyamatban való részvételt a 184/1996. (XII. 11.) Korm. rendelet (a területfejlesztési koncepciók és programok, valamint a területrendezési tervek egyeztetésének és elfogadásának rendjéről) szabályozta, melyet 2001-ben módosítottak. A rendelet a kidolgozás folyamatát illetően szinte kizárólag az egyes területi szintek (top-down logika), illetve a központi kormányzati szervek bevonására vonatkozóan adott iránymutatást. A kidolgozás folyamatában a partnerséget részletesen nem szabályozta, a nem közjogi szereplők közül kizárólag a kamarákat, illetve a területileg érintett felsőoktatási intézményeket jelölte meg (Fodor et al. 2003). A programot a megyei önkormányzat megbízásából a Magyar Tudományos Akadémia Regionális Kutatások Központjának pécsi székhelyü Dunántúli Tudományos Intézete készítette, ami - nagy múltú területi kutatásokkal foglalkozó szervezet lévén - megfelelő szakmai garanciát jelentett.

A dokumentum elsősorban a megye belső területi egyenlőtlenségeire fókuszál. A helyzetelemzés felépítése kistérségi logikájú: bemutatja az egyes kistérségeket a megyei átlaghoz viszonyítva, rávilágít az egyes térségeken belüli egyenlőtlenségi viszonyokra, a mikrotérségi, települési specifikumokra, s külön hangsúlyozza a vonzáskörzeti (centrum-periféria) kérdéseket. Ennek oka, hogy a megyei önkormányzat a megyei program kidolgozását megelőzően elkészíttette az egyes kistérségek fejlesztési dokumentumait, a megyei program ennek alapján készült, így egyértelműen bottom-up szemléletű. A megyei program komoly hiányossága azonban, hogy miközben hosszú távú célként „új alapokon a korábbi pozíciók visszaszerzése" (BMTT 2003,22.) jelenik meg, továbbá az egyes stratégiai célok is a megye egésze elmaradottságának leküzdését helyezik előtérbe, az elemzésből gyakorlatilag teljesen hiányzik a megye országon belüli pozicionálása. Egyedül Pécs mint megyeszékhely (és régióközpont) jelenik meg centrumtérségként. Ugyanakkor a területi gondolkodás meglétét igazolja, hogy stratégiai célként megjelenik a megyén belüli jelentős különbségek mérséklésének igénye is (BMTT 2003). 
A dokumentum nem tartalmaz intézményi (stakeholder) elemzést. Az egyes operatív programok kapcsán a felelősöket „gesztorszervezetként” jelöli meg, s ugyan nem határozza meg annak pontos jelentését, de felsorolja a lehetséges közreműködő szervezetek (partnerek) körét. A széles partneri kör megjelenítése intézményi hiátusra enged következtetni, ahogy az operatív programok között említett gazdaságfejlesztési iroda felállításának szükségessége is. A megyei területfejlesztési tanácsot a dokumentum több ponton is nevesíti, megjegyezve, hogy operatív kapacitásokkal és érdemi hatáskörrel nem rendelkezik. A megyei fejlesztési tanács munkaszervezete a megye által kezelt decentralizált források (TEKI, CÉDE) menedzsmentjét látta el, a fejlesztési feladatok (projektgenerálás) a megyei önkormányzat szervezetén belül maradtak. Mivel a megye által kezelt decentralizált források zömében kis összegü, általános (kis)települési életminőség-javító beruházásokat támogattak, melyek az önkormányzatok alulfinanszírozottságát próbálták enyhíteni (Márton 2009), továbbá a programhoz való illeszkedést a projektkiválasztás során figyelembe vették, a program térségi logikája és bottom-up szemlélete végeredményben illeszkedett a megye akkori területfejlesztési feladataihoz.

A 2003-as megyei program születése egybeesett a regionális intézményrendszer kiépítésével. A területpolitika folyamatosan regionális fókuszúvá vált, melyet a közelgő uniós csatlakozás is elősegített. A 2004-2006-os időszakban futó, országosan egységes Nemzeti Fejlesztési Terv (NFT) Regionális Operatív Programja (ROP) nem tekinthető valódi megyei vagy regionális programnak. A ROP kidolgozása során a részvételre vonatkozóan nem létezett jogszabály (Fodor et al. 2003), mivel a ROP-ot nem a Tft. hozta létre. Ettől függetlenül a különböző területi szintű közjogi szervezetek: országos dekoncentrált szervek, felsőoktatási intézmények, civil szervezetek, kiegészülve a gazdasági élet képviselőivel (kamarák, vállalkozásfejlesztési központok, inkubátorházak) a kidolgozásban valamilyen szinten közremüködtek, jellemzően mühelymunkákon való részvétel formájában (Fodor et al. 2003). A kezdeti, a regionális fejlesztési ügynökségek munkájára épülő régióspecifikus intézkedéseket is tartalmazó változat helyett végül egy három prioritásra kiterjedő, kizárólag tematikus ROP került elfogadásra (Márton 2004). A regionális dimenzió erősítése érdekében elkészültek az ún. regionális akciótervek (RAT), melyek nem voltak részei a hivatalos programdokumentumnak, azonban szerepük volt a projektkiválasztásban (Márton 2004).

\section{A regionális léptékű fejlesztéspolitika előtérbe kerülése 2007-től}

A 2007-2013-as programozási időszak általában a területi gondolkodás megerősödését, a régiók jelentőségének növekedését hozta magával. Ezzel összhangban Magyarországon a Nemzeti Stratégiai Referenciakeret részeként önálló operatív program készült valamennyi NUTS 2 régióra, beleértve a Dél-Dunántúlt is. A regio- 
nális operatív programok kidolgozása magával hozta az intézményrendszer regionális fókuszúvá válását, mely a megye és a megyei fejlesztési tanács - bár területfejlesztési funkcióit a törvény elvileg nem csorbította - szerepének háttérbe szorulását jelentette. A megyei tervezés szerepének leértékelődését mutatja, hogy a 2007-2013-as időszakban Baranyában sem megyei koncepció, sem megyei program nem készült. Ennek oka a megyei fejlesztési tanács szerepének visszaszorulása; a megye a tervezéshez megfelelő forrásokkal nem rendelkezett, a regionális tervezési folyamat „nagyüzemi” időszakában a megyei tervezés nem volt prioritás.

A regionális operatív programok kidolgozását hosszú előkészítés előzte meg, mely a Dél-Dunántúli Operatív Program (DDOP) esetében kifejezetten aprólékos folyamatot jelentett. A koordinációval a regionális fejlesztési tanácsokat bízták meg, így a programot a Dél-Dunántúli Regionális Fejlesztési Ügynökség (DDRFÜ) készítette. Az egyes, a program várható tematikus lefedettségéhez illeszkedő területeken stratégiai fejlesztési programok születtek, amelyek alapján elkészült a régió stratégiai célrendszere (Márton 2004). Az időközi dokumentumok megvitatása és elfogadása érdekében felállították a Dél-Dunántúli Térségi Tervezői Hálózatot a DDRFÜ koordinációjával, megyei, megyei jogú városi és kistérségi résztvevőkkel, valamint egy szakmai tervező hálózatot is, mely tematikus szakértői kapacitásokat jelentett (Márton 2004). Társadalmasítási rendezvényekre (mintegy 30 workshopra) jellemzően kistérségi szinten került sor. A jogszabályban előírt társadalmi vitát megelőzően készült anyag így már egy igen széles körben megvitatott dokumentum volt (Kormány 2007). Ezt követte az országos egyeztetési folyamat, mely a Nemzeti Fejlesztési Ügynökség (NFÜ) koordinációjával zajlott, mely további, nagyszámú vélemény beépítését tette lehetővé.

A DDOP által megfogalmazott specifikus célok - hasonlóan a többi regionális operatív programhoz - jellemzően ágazati jellegüek, amelyek azonban tartalmaznak utalást a helyi specifikumokra (helyi adottságokra épülo", régión belüli különbségek csökkentése). A program külön fejezetet szentel a területi kérdéseknek, melynek során három térkategóriát határoz meg: országos fejlesztési pólus, regionális növekedési zónák, illetve vidéki térségek. A három kategória lehatárolására (1. ábra) vonatkozóan a régión belül komoly vita bontakozott ki. A program országos fejlesztési pólusként Pécs szélesebb térségét (Szentlőrinc-Siklós-Pécsvárad-Komló) nevezte meg, valamint Mohács térségét a Paks-Szekszárd-Mohács növekedési zóna részeként. A többi (Dráva-mente, Zselic, Hegyhát) vidéki térségként, külső és belső perifériaként került meghatározásra. A prioritásokat - az egyes regionális OP-k vonatkozásában gyakorlatilag egységesen - szektorálisan jelölték ki, az egyes prioritásokon belül azonban további területi preferenciákat határoztak meg (turizmus: termék-magterület mátrix; humán közszolgáltatások és közlekedés: kis- és mikrotérségi központok, hátrányos helyzetű térségek), melyek szintén vitát generáltak. Az integrált városfejlesztési prioritáson belül külön nevesítették Pécset mint az Európa Kulturális Fővárosa projekthez kapcsolódó beruházások helyszínét. 
1.ábra: Térkategóriák a Dél-Dunántúli Operatív Programban (2007-2013) Area categories applied in the South Transdanubia Operational Programme (2007-2013)

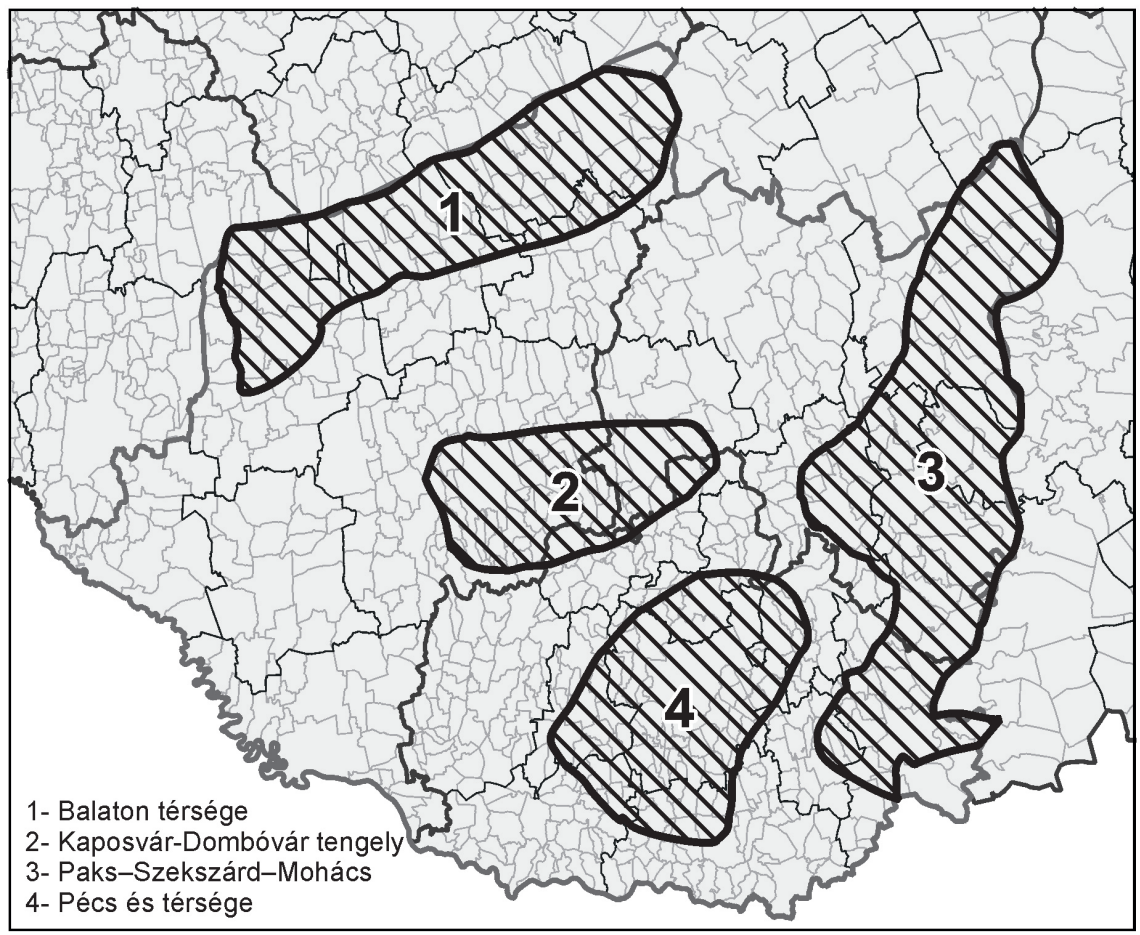

Forrás: Kormány 2007, 43. alapján saját szerkesztés

Mivel a DDOP - a korábbi megyei programtól eltérően - jelentős európai uniós forrással is rendelkezett, a végrehajtáshoz kiterjedt intézményi struktúra kapcsolódott. Maga a program csak a végrehajtás adminisztratív oldalát írja le, külön kiemelve a közreműködő szervezetek (ezen belül a DDRFÜ) szerepét. Ezen kívül utal a kedvezményezettek mint a végrehajtásban részt vevő szervezetek körére, a program azonban szervezeti kérdésekre nem tér ki, új szervezet felállítását nem irányozza elő.

A program végrehajtásában a regionális intézményrendszer (regionális fejlesztési tanács, regionális fejlesztési ügynökség) szerepe sokrétű volt. Az 1998-ban létrejött regionális fejlesztési ügynökségek új feladatkörüknek köszönhetően jelentős szervezetfejlesztésen mentek keresztül (Józsa 2018). A programozáson túl az akciótervek készítése, a kiírások véleményezése (tervezési bizottság, pályázatelőkészítő munkacsoport), a projektkiválasztással kapcsolatos feladatok (pályázatok befogadása, értékelése, döntéselőkészítés) az intézményrendszert több ponton érintette, és érdemi hatásköröket adott az ott dolgozóknak. 2012-től, a regionális tanácsok megszünését követően, a döntéshozatal centralizáltabbá vált, az Irányító Hatóság (IH) kezében lévő hatáskörök, a közreműködő szervezetek rová- 
sára, bővültek (Simó 2019). A regionális fejlesztési ügynökségnek azonban a programvégrehajtáson túlmutató szerepe is volt: segítette a projektek megvalósításában közreműködő kedvezményezetteket, ezáltal igyekezett megfelelni a nyugat-európai fejlesztési ügynökségi modellnek. Ennek egyik kiemelt eszköze volt a saját projektek indítása, azon belül is kiemelten a nemzetközi együttmüködési projektekben való részvétel (melyben a dél-dunántúli ügynökség országosan is az egyik legaktívabbnak bizonyult). Az ügynökségek közreműködő szervezeti feladatain túlmutató finanszírozás elapadása után ezek a funkciók folyamatosan leépültek (Simó 2019).

\section{A megyei fókuszú regionális fejlesztéspolitika visszatérése - 2014-2020}

A Tft. 2011-es módosítása megszüntette a regionális fejlesztési tanácsokat, a területfejlesztés koordinációját az egyéb funkcióitól megszabadított megyei önkormányzatok hatáskörébe utalta. Ezzel párhuzamosan megyei szinten összevonták a központi (dekoncentrált) államigazgatási szerveket, melyekből megalakultak a megyei kormányhivatalok, amelyek vezetőit (mint kormánymegbízottat) a miniszterelnök nevezi ki. A területfejlesztési funkció önkormányzathoz telepítése ellenére a megyei intézményrendszer elvesztése összességében inkább szűkítette a megyei önkormányzatok mozgásterét, s ez anyagi helyzetükön és szakembergárdájuk összetételén is meglátszott.

A 2014-2020-as uniós programozási időszakra felkészülve a megyei önkormányzatok koncepciót és programot készítettek, melyre központi költségvetési forrást kaptak. A két dokumentum elkészítése központilag meghatározott módszertan mentén történt, a Nemzetgazdasági Tervezési Hivatal (NTH) felügyelete alatt. A tervezés folyamatát, beleértve a részvétel kérdését is, a többször módosított 218/2009. (X. 6.) Korm. rendelet szabályozta. Ennek értelmében a részvétel megvalósítására partnerségi terv készült, mely az érdekeltek jogszabályban előírt széles körének bevonását irányozta elő. Ugyanakkor a 2013-tól hatályos szabályozás lehetővé tette a bevonandó partneri kör „testre szabását”, azaz a tervet készítő önkormányzat maga dönthetett a bevonandók köréről. A partnerségi terv kidolgozása megelőzte magának a dokumentumnak az elkészítését, s ez éppúgy lehetőséget adott a bevonás pontos átgondolására, mint a tervben nem szereplő szervek mellőzésére (Bajmócy et al. 2017). Személyes egyeztetéseket folytattak, rendezvényeket (workshopok) szerveztek, illetve online bevonási eszközöket is alkalmaztak (BMÖ 2013). Ahogy azt a dokumentum készítése kapcsán az interjúalanyok jelezték, a széles lefedettséget biztosító megyejárás során a megyei vezetők igyekeztek felhívni a figyelmet a koncepció kidolgozásában rejlő lehetőségekre, vagyis arra, hogy Baranya elmaradott helyzetének feltárása, a helyi javaslatok megfogalmazása lehetőséget ad arra, hogy a megye- a fejletlen északkeleti megyékhez hasonló - figyelemben részesüljön a 2014-2020-as programozási időszakban. 
A megyei koncepciót és programot a megyei önkormányzat belső munkában készítette el, bár több területen (pl. Ős-Dráva program) támaszkodott külső szakértők inputjaira. A 2014-ben készült megyei koncepció a területi és tematikus célokat egyenrangúan kezeli, a helyzetelemzés több ponton is tartalmaz helyi specifikumokat, járási, térségi hivatkozásokat. Ugyanakkor - a 2003-as dokumentummal szemben - jobban fókuszál a megye országon belüli helyzetére, amellett, hogy a belső egyenlőtlenségek kérdését is tárgyalja. A fejlesztési környezet leírásakor az anyag erősen támaszkodik az országos koncepcióra (Nemzeti Fejlesztés 2030), az országos fejlesztési pólusokra. Az országos stratégiákra való hivatkozás igen terjedelmes, különösen a közlekedés vonatkozásában, ez az anyag top-down jellegét erősíti, mely - az interjúalanyok elmondása alapján - a központi szint kifejezett elvárása volt. Ugyanakkor pozitív vonás, hogy a dokumentum a megyét nem elszigetelten elemzi, hanem kitekint a környező megyékre, beleértve a két szomszédos horvát megyét is. A releváns stratégiák, dokumentumok kapcsán a bottom-up jelleg a megyei jogú városi koncepció (Pécs), illetve az integrált városfejlesztési stratégiák említésében jelenik meg.

A dokumentum a három tematikus cél mellett területi célokat is megfogalmaz, melyek egy-egy megyén belüli terület sajátos adottságaival vagy fejlettségével függenek össze. Ezek a területek a következők: hátrányos helyzetű térségek, mint az Ős-Dráva program területe, Szigetvár, Sásd; Pécs-Komló térsége; Mohács-Bóly valamint Villány-Siklós-Harkány térsége; határ menti térségek (BMÖ 2014a, valamint 2. ábra), ugyanakkor a tematikus célok kibontásánál a területi preferenciák nem jelennek meg, kivéve a közlekedési infrastruktúra fejlesztésére vonatkozó célt, bár ott is a határon átnyúló szemlélet, a nagytérségi kapcsolatok kialakítása meghatározó. Ebből következően a tematikus és területi célok közötti koherencia nem teljesen világos. A tematikus célok kibontásánál területi dimenzióban csak Pécs és térsége jelenik meg. A területi célok kifejtése sem tartalmaz pontosabb utalást az adott térségen belüli területi lehatárolásokra. Ahogy az a koherencia-vizsgálatból is látszik, a megyei dokumentum készítése során az országos tervekhez való illeszkedés volt a meghatározó szempont.

A javaslattételi munkarész intézményi fejezete - összhangban a kormányrendelettel - megkülönbözteti a megye által saját hatáskörben és az egyéb intézményeken keresztül elérhető célokat. Magának a koncepciónak a végrehajtását nem írja le az anyag, a megye koordinatív szerepéből nem lehet következtetni a pontos feladatokra sem. A dokumentum viszont nevesíti az érintett kormányzati szerveket és a közszférán kívüli szereplőket, felsorolásjelleggel. Bár a koncepció közvetlenül nem kötődik uniós programok végrehajtásához, a végrehajtási fejezet intézményi része dominánsan az uniós programvégrehajtás központi mechanizmusát taglalja, nem a megyét közvetlenül érintő szempontokat. Így az egyes közremüködő szervezetek bemutatása is csak említésszerü.

A koncepcióval egy időben készült Baranya Megyei Területfejlesztési Program szintén a Tft. által meghatározott dokumentum, kapcsolata azonban valamennyivel 
2. ábra: Területi célok kijelölése a Baranya megyei koncepcióban és programban 2014-2020 Definition of territorial objectives in the Baranya county concept and programme 2014-2020

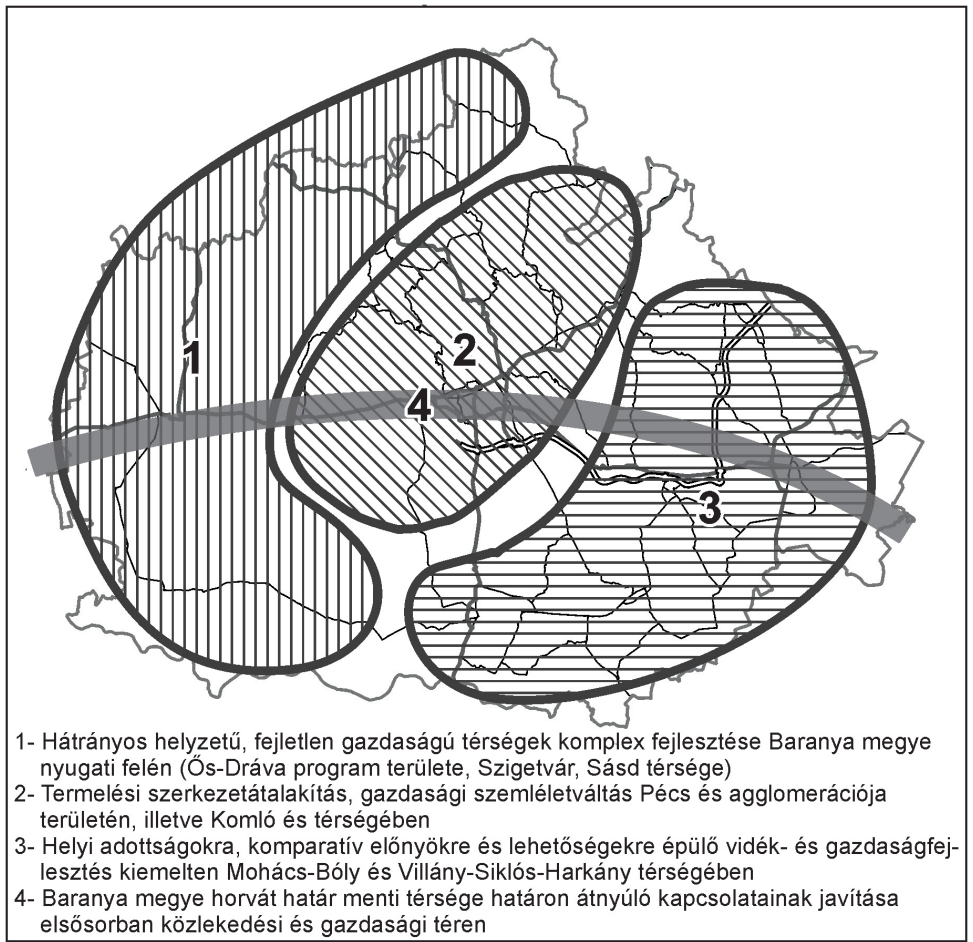

Forrás: BMÖ 2014a, 21. alapján saját szerkesztés

közvetlenebb az uniós kohéziós politikával. Ennek ellenére a program is az ún. teljes tervezés módszerével készült, azaz nem kizárólag a kohéziós politika által meghatározott tematikus keretekben irányoz elő beavatkozásokat. A bevonandó szereplők körét ugyancsak a 218/2009. (X. 6.) Korm. rendelet szabályozta. A folyamat hasonlóan zajlott ahhoz, ami a koncepció kidolgozásakor történt. A program alapjában véve a koncepcióban lefektetett (tematikus és területi) célokra reflektál, az egyes prioritások és intézkedések megfogalmazása azonban nem a területi, hanem a tematikus célokhoz illeszkedik, így a koncepció területi céljaihoz való illeszkedés csupán asszociatív. A területi szempontok a megye számára kiemelt fontosságú komplex stratégiai programokban jelennek meg, melyek erős területi jelleggel bírnak (Ős-Dráva, Hegyhát, Pécs, Komló, Zengő - BMÖ 2014b). Ezen programok meghatározásakor az interjúalanyok közlése alapján az volt a cél, hogy a megye területét nagyjából teljesen lefedje. Az egyes prioritások részletes leírásában szerepelnek a területi hivatkozások, sőt, az egyes intézkedések leírása után a dokumentum területi fókuszt határoz meg, bár ezek jellemzően az adott ágazat területi jelenlétére utaló általános megfogalmazások (pl. mezőgazdasági termeléssel érintett területek, hátrányos helyzetű térségek). 
A megyei program ötödik, végrehajtási fejezete - hasonlóan a koncepcióhoz - elsősorban a közreműködő szervezetek bemutatására szorítkozik. A program valamennyi prioritás esetében megnevezi magát a megyei önkormányzatot, ám konkrét, lehatárolt felelősség nélkül. Ezen felül számos országos, központi hatáskörrel rendelkező szervet megemlít. A 9. fejezetben bemutatott együttműködési programok leírása nem tartalmaz intézményi elemeket. Az Ős-Dráva program kapcsán hivatkozott rendelet különböző minisztériumokat említ mint végrehajtásért felelős szerveket, illetve a program tartalmazza az Ős-Dráva Programiroda felállítását is. A programirodát végül a Széchenyi Programiroda mint országos nonprofit területfejlesztési szervezet keretén belül állították fel, kémesi telephellyel. Egy program esetében megjelenik a Pécsi Tudományegyetem is, több helyen pedig városokat neveznek meg.

A két Tft.-ben definiált megyei tervdokumentum mellett mindenképpen meg kell említeni a megyei integrált területi programot (ITP), mely közvetlenül kapcsolódik a kohéziós politika végrehajtásához. Az ITP egyfelől illeszkedik a megyei koncepcióhoz és programhoz, másfelől közvetlenül a Terület- és Településfejlesztési Operatív Program (TOP) - mint központilag koordinált kohéziós politikai eszköz - végrehajtását szolgálja. Az ITP-t ilyen értelemben tekinthetjük a DDOP „utódjának” is. Az ITP a „forrásfelhasználás hatékonnyá tétele érdekében (...) integrált, stratégiai (...) dokumentum, amely a helyi igényekkel összhangban a rendelkezésre álló TOP forráskeretek felhasználásának szerkezetét, elvárt eredményeit és ütemezését támasztja alá" (BMÖ 2020, 3-4.).

Az ITP kapcsán fontos megjegyezni, hogy ez nem egyezik meg a 2014-2020-as programozási időszakban bevezetett integrált területi eszközzel, az ITI-vel. Az ITI egy várostérségre vonatkozó, integrált szemléletben készült területi stratégia, melynek finanszírozása több forrásból, helyi/térségi részvétellel és döntéshozatallal (governance) zajlik. Ezzel szemben az ITP nem várostérségekre, hanem az egyes megyékre és a megyei jogú városokra külön-külön készül, nem funkcionális szemléletben, hanem a közigazgatási határok mentén, tehát kettéválasztja a központot és funkcionális térségét. Finanszírozása kizárólag a TOP eszközeiből történik (bár azon belül az ERFA és az ESZA forrásai is megjelennek), végrehajtásában pedig a megye/megyei jogú város és az irányító hatóság működik együtt, tehát a meglévő közigazgatási kereteket átlépő, térségi részvételi mechanizmusok nem léteznek.

A másik integrált eszköz, a CLLD alkalmazására a TOP 7. prioritása keretében került sor, azonban kizárólag a megyei jogú városok számára elérhető. Ezen elem keretében a városi közösségek fejlesztésére a megyei jogú városok ún. Helyi Közösségi Fejlesztési Stratégiákat készítenek, melynek megvalósítása érdekében pályázati rendszert, helyi értékelési és kiválasztási rendszert működtetnek, melyben a szavazatok több mint 50 százalékát állami hatóságnak nem minősülő szervezeteknek kell adniuk (Lechner Tudásközpont 2017). ${ }^{1}$ 
Az ITP végrehajtása során alkalmazott ún. területi kiválasztási rendszer hivatott arra, hogy a projektek kiválasztásánál érvényesüljenek a megyei célok. A területi kiválasztási rendszer a következő négy szempontot veszi figyelembe: illeszkedés a megyei területfejlesztési programokhoz és a vonatkozó indikátorokhoz; hozzájárulás a belső területi kiegyenlítődéshez - a megyei program 4. stratégiai céljához való illeszkedés (társadalmi felzárkózás elősegítése); hozzájárulás a gazdasági növekedéshez; hozzájárulás a munkahelyteremtéshez (BMÖ 2020, 6-7.).

Az ITP kidolgozása - hasonlóan a megyei programhoz - az előre meghatározott és elfogadott partnerségi terv mentén történt, a részvétel azonban - az interjúalanyok közlése szerint - meglehetősen formális volt. Bár az ITP is belső munkában készült, annak vázát központilag bocsátották rendelkezésre, amely gyakorlatilag a TOP prioritásai által megfogalmazott indikátorok megyei lebontását tartalmazta, annak költségvonzatával együtt. A dokumentumban a helyi tudás csupán a megyei koncepcióhoz és programhoz való illeszkedésen keresztül jelenik meg. A megyei programhoz való illeszkedést pedig a program indikátorainak elérésében való szerepvállaláson, a területi kiegyenlítéshez, a gazdasági növekedéshez, munkahelyteremtéshez való hozzájáruláson keresztül lehet megragadni. Ugyanakkor a területi kiválasztási rendszer kritériumait területspecifikus melléklet formájában az IH terjeszti a Monitoring Bizottság elé, s azon a megye menet közben nem tud változtatni. Ugyanakkor, egyik interjúalanyunk szerint, a minimumpontot elért projektek esetében a megye gyakorlatilag szabad kezet kapott a projektek kiválasztásában.

Bár az ITP maga nem tartalmaz részletes végrehajtási fejezetet, a Nemzetgazdasági Minisztérium mint IH által kiadott útmutató részletesen bemutatja a megyei önkormányzat mint területi szereplő feladatát az ITP kidolgozásában és végrehajtásában. A megyei önkormányzat felelős az ITP elkészítéséért, benyújtásáért, a jóváhagyás viszont már az IH feladata. A projektkiválasztás során alkalmazott ún. területi kiválasztási rendszer keretében a megye a döntésben részvételi joggal rendelkezik (NGM 2015). A TOP megyei forráskeretének allokálásakor a megyének lehetősége van az egyes prioritástengelyek közötti súlyozásra, valamint - amennyiben a megyében ilyet kijelöltek - a kiemelt fejlesztési célterület számára forrásokat különíthet el. Ilyen kategóriát a baranyai ITP nem tartalmaz. Emellett véleményezési joga van az IH által készített felhívások esetében, részt vesz a támogatási kérelmek bírálatában, valamint részt vehet a kiválasztott projektek menedzsmentjében is (NGM 2015). A program végrehajtása azonban a megyei adminisztráción kívül, központi kormányzati szerveken keresztül zajlik, a Magyar Államkincstár területi igazgatóságai mint közreműködő szervezetek bevonásával.

A végrehajtás kapcsán a dokumentum kitér a programot koordináló megyei önkormányzat két saját megvalósítású projektjére. Az eredetileg megyei koordinációjú, rövid ellátási lánc kialakítását célzó projekttől a megye a 2020-as ITP-módosítás szerint elállt. A megyei kerékpárút-koncepció részeként a Pécs-Siklós kerék- 
3. táblázat: A Baranya megyei koncepció, program és a Terület- és Településfejlesztési Operatív Program (TOP) prioritásai közötti kapcsolat

Linkages between the concept and programme of Barany a county and priorities of the Territorial and Settlement Development Operational Programme (TOP)

A megyei terïletfejlesztési Kapcsolódó megyei stratégia cél A megvalósitást szolgáló kapcsolóprogram prioritásai

\begin{tabular}{|c|c|c|}
\hline I. prioritás: A helyi erőforráso- & 1. Helyi gazdaságok fejlesztése & TOP 1. prioritás \\
\hline $\begin{array}{l}\text { kon alapuló gazdaság megerősí- } \\
\text { tése a lokális gazdasági környe- } \\
\text { zet integrált fejlesztésével }\end{array}$ & $\begin{array}{l}\text { 3. Piaci igényekre reagálni } \\
\text { képes emberi erőforrás-fej- } \\
\text { lesztés }\end{array}$ & TOP 5. prioritás \\
\hline $\begin{array}{l}\text { II. prioritás: Külső erőforrásokra } \\
\text { is támaszkodó, a termelési } \\
\text { kapacitások növelésére alapo- } \\
\text { zott versenyképes gazdaság } \\
\text { megteremtése a megyében }\end{array}$ & $\begin{array}{l}\text { 2. Tartós növekedésre képes } \\
\text { gazdaság megteremtése }\end{array}$ & $\begin{array}{l}\text { TOP 1. prioritás } \\
\text { TOP 5. prioritás }\end{array}$ \\
\hline $\begin{array}{l}\text { III. prioritás: A piaci igényekhez } \\
\text { rugalmasan illeszkedő képzési } \\
\text { struktúra kialakítása és fejlesz- } \\
\text { tése }\end{array}$ & $\begin{array}{l}\text { 3. Piaci igényekre reagálni } \\
\text { képes emberi erőforrás-fej- } \\
\text { lesztés } \\
\text { 4. Társadalmi felzárkóztatás }\end{array}$ & $\begin{array}{l}\text { TOP 1. prioritás } \\
\text { TOP 5. prioritás }\end{array}$ \\
\hline $\begin{array}{l}\text { IV. prioritás: Az élhetőbb telepü- } \\
\text { lések, élhetőbb közösségek } \\
\text { kialakulását szolgáló komplex } \\
\text { fejlesztések, egészségtudatosság } \\
\text { és egészségügyi prevenció az } \\
\text { egészséges munkaképes társada- } \\
\text { lom biztosítása érdekében }\end{array}$ & $\begin{array}{l}\text { 3. Piaci igényekre reagálni } \\
\text { képes emberi erőforrás-fej- } \\
\text { lesztés } \\
\text { 4. Társadalmi felzárkóztatás }\end{array}$ & $\begin{array}{l}\text { TOP 2. prioritás } \\
\text { TOP 4. prioritás } \\
\text { TOP 5. prioritás }\end{array}$ \\
\hline $\begin{array}{l}\text { V.prioritás: A természeti erőfor- } \\
\text { rások fenntartható használatán } \\
\text { alapuló és klímatudatos környe- } \\
\text { zetgazdálkodás feltételeinek } \\
\text { megteremtése }\end{array}$ & $\begin{array}{l}\text { 5. Stratégiai erőforrások fenn- } \\
\text { tartható használata }\end{array}$ & $\begin{array}{l}\text { TOP 2. prioritás } \\
\text { TOP 3. prioritás }\end{array}$ \\
\hline $\begin{array}{l}\text { VI. prioritás: Az elérhetőség } \\
\text { javítása, fenntartható közleke- } \\
\text { dési rendszerek létrehozásának } \\
\text { előmozdítása }\end{array}$ & $\begin{array}{l}\text { 6. Elérhetőség és mobilitás } \\
\text { javítása } \\
\text { 7. Nagytérségi csomóponttá } \\
\text { válás }\end{array}$ & $\begin{array}{l}\text { TOP 1. prioritás } \\
\text { TOP 3. prioritás }\end{array}$ \\
\hline
\end{tabular}

Forrás: BMÖ 2020, 9.

párút előkészítése és kialakítása viszont továbbra is szerepel a projektek között. A megye szerepvállalását a projekt több települést érintő jellege, az egységes koordináció, a hasonló megyei projektekben szerzett tapasztalat, illetve a célterületi önkormányzatok kapacitáshiánya indokolja (BMÖ 2020). A projekt kijelölésével és megyei hatáskörben való megvalósításával az önkormányzat egy olyan feladatot vállalt magára, mely az alsó-középszintủ területi koordinációs intézményrendszerben meglévő hiátust igyekszik kitölteni és hozzáadott értéket eloaállítani. 
A 2014-2020-as programozási időszakban a jogszabály szerint a megye a megyei jogú város bevonásával készíti el a koncepciót és a programot, erre a törvény létrehozza a megyei konzultációs fórumot. Ettől függetlenül Pécs Megyei Jogú Város külön városfejlesztési koncepciót készített 2014-ben, mely nem a Tft., hanem a 314/2012. (XI. 8.) Korm. rendelet alapján készült (Pécs MJV 2014). Ugyanakkor, a TOP végrehajtása kapcsán a megyei jogú városokra, így Pécsre is, külön ITP készült, mely a TOP 6 . prioritása intézkedéseire határoz meg forráskereteket (mely gyakorlatilag a TOP 1-5. prioritásainak struktúráját követi). Így, bár a Tft. szempontjából a megyei jogú város része a megyének, a kohéziós politika végrehajtása szempontjából külön entitásnak számít.

\section{Összefoglalás és javaslatok}

A 2003 óta eltelt időszak három, jól elkülöníthető, az uniós fejlesztéspolitika és a magyar közpolitika ciklusaihoz illeszkedő korszakból áll. A 2003-as megyei program a megyén belüli területi egyenlőtlenségek csökkentését tűzte ki célul, a mikroszintü önkormányzati fejlesztések megalapozását szolgálta. A 2007-2013-as időszakban, a területfejlesztési politika regionalizációjának idején nem készült megyei koncepció és program. A DDOP a három dél-dunántúli megye lecsúszásának megállítását tűzte ki célul, konkrét uniós eszközök segítségével. A 2014-es megyei koncepció a megye helyzetét igyekszik pozicionálni az ország gazdasági vérkeringésében, illetve a környező makroregionális térben, határon is átnyúló kitekintéssel. A megyei koncepció, a megyei program és az ITP közbeiktatásával szintén rendelkezik uniós fejlesztési forrásokkal. A három korszak dokumentumai az alkalmazott place-based szempontok szerint vizsgálva jelentős eltéréseket mutatnak, melyet strukturált formában mutat a 4. táblázat.

A három korszak dokumentumainak keresztmetszeti vizsgálata alapján elmondható, hogy a területi bevonás szabályozottsága mind top-down, mind bottomup szempontból fokozatosan erősödött. Míg a 2003-as program idején csupán a Tft. által előírt szűk kör bevonása volt kötelező, a helyi stakeholderek részvételét pedig a megyére bízták, addig az uniós csatlakozás után elfogadott dokumentumok készítésére már szélesebb körü partnerség volt jellemző. A DDOP kidolgozását a Tft. által előírtnál lényegesen szélesebb részvételi folyamat jellemezte. A 2014-es dokumentumokat megelőzően partnerségi terv született, mely - bár lehetőséget adott volna a részvétel szelektív értelmezésére - szintén igen széles körű bevonással készült. A területi tudás, a területi preferenciák, ha eltérő fókusszal is, mindhárom időszak dokumentumaiban megtalálhatók. A 2003-as program kistérségi fókuszú, bár céljai, prioritásai kizárólag tematikusak. A 2007es DDOP-ban a területi logika szintén több vetületben megjelenik (általános térkategóriák, prioritások területi preferenciái). A 2014-es koncepció és program ugyancsak számos vonatkozásban tartalmaz területi preferenciákat. Ezzel szem- 
4. táblázat: A három időszak megyei programjainak place-based szempontú áttekintése Overview of the county programmes of the three periods from the perspectvie of the place-based approach

\begin{tabular}{|c|c|c|c|}
\hline & $\begin{array}{l}\text { bevonás } \\
\text { ber }\end{array}$ & 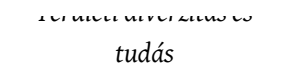 & reyon \\
\hline $\begin{array}{l}\text { Baranya megye terü- } \\
\text { letfejlesztési program- } \\
\text { ja } 2003\end{array}$ & $\begin{array}{l}\text { Top-down: központi } \\
\text { koordináció nincs. } \\
\text { Bottom-up: nem szabá- } \\
\text { lyozott bevonási folya- } \\
\text { mat. A kidolgozást he- } \\
\text { lyi kutatóintézet végzi, } \\
\text { elsősorban kistérségi } \\
\text { és helyi bevonás } \\
\text { mellett. }\end{array}$ & $\begin{array}{l}\text { A megye belső viszo- } \\
\text { nyaira fókuszál (belső } \\
\text { területi kiegyenlítés). } \\
\text { Megyei szintű területi } \\
\text { célokat nem tartalmaz. }\end{array}$ & $\begin{array}{l}\text { Megyei területfejlesz- } \\
\text { tési tanács kapacitásai } \\
\text { hiányosak, gazdaság- } \\
\text { fejlesztési iroda felállí- } \\
\text { tását javasolja. }\end{array}$ \\
\hline $\begin{array}{l}\text { Dél-Dunántúli Operatív } \\
\text { Program (DDOP) 2007- } \\
2013\end{array}$ & $\begin{array}{l}\text { Top-down: erős közpon- } \\
\text { ti koordináció (NSRK } \\
\text { része), regionális pre- } \\
\text { ferenciák beépítésének } \\
\text { lehetősége. } \\
\text { Bottom-up: széles körű } \\
\text { egyeztetések, megala- } \\
\text { pozó stratégiai fejlesz- } \\
\text { tési programok készí- } \\
\text { tése, tervezői hálózat. }\end{array}$ & $\begin{array}{l}\text { A régió lecsúszásának } \\
\text { megállítására fókuszál. } \\
\text { Három térkategória } \\
\text { megfogalmazása. Az } \\
\text { egyes prioritások is } \\
\text { rendelkeznek területi } \\
\text { preferenciákkal, regi- } \\
\text { onális döntéselőkészítő } \\
\text { mechanizmusok. }\end{array}$ & $\begin{array}{l}\text { Tervezési, pályázatelö- } \\
\text { készítési és program- } \\
\text { végrehajtási intézmé- } \\
\text { nyi háttér kialakítása } \\
\text { regionálisan. } \\
\text { A regionális fejlesztési } \\
\text { ügynökség szerepe a } \\
\text { programvégrehajtá- } \\
\text { son túlmutató (pro- } \\
\text { jektgenerálás, nemzet- } \\
\text { közi kapcsolatok). }\end{array}$ \\
\hline $\begin{array}{l}\text { Baranya Megyei Terü- } \\
\text { letfejlesztési Koncep- } \\
\text { ció 2014-2020 } \\
\text { Baranya Megyei Terü- } \\
\text { letfejlesztési Program } \\
2014-2020 \\
\text { Baranya Megye Integ- } \\
\text { rált Területi Programja } \\
\text { 2015-2020 }\end{array}$ & $\begin{array}{l}\text { Top-down: erős közpon- } \\
\text { ti koordináció, orszá- } \\
\text { gos tervekhez való } \\
\text { szoros illeszkedés. Az } \\
\text { ITP központilag leosz- } \\
\text { tott célokat és forráso- } \\
\text { kat tartalmaz. } \\
\text { Bottom-up: bevonás } \\
\text { rendeletben meghatá- } \\
\text { rozott partnerségi terv } \\
\text { mentén. }\end{array}$ & $\begin{array}{l}\text { A megye helyzetének } \\
\text { újrapozicionálása az } \\
\text { országon belül és } \\
\text { makroregionálisan. } \\
\text { Tematikus és területi } \\
\text { célok egyenrangú } \\
\text { kezelése: négy területi } \\
\text { cél meghatározása. } \\
\text { Területi célok megje- } \\
\text { lenítése a projektkivá- } \\
\text { lasztási rendszerben. } \\
\text { Az ITP esetében hiány- } \\
\text { zik a funkcionális } \\
\text { szemlélet: kettéválik a } \\
\text { megye és a megyei } \\
\text { jogú város. }\end{array}$ & $\begin{array}{l}\text { Gyenge megyei kapaci- } \\
\text { tások, koordináció } \\
\text { országos hatáskörű } \\
\text { szervekhez telepítése } \\
\text { (Ős-Dráva - SZPI), } \\
\text { megyei saját projektek } \\
\text { minimális száma. } \\
\text { Relatíve erősebb } \\
\text { megyei jogú városok. } \\
\text { Az ITP végrehajtását } \\
\text { szolgáló intézmény- } \\
\text { rendszer adminisztra- } \\
\text { tív fókuszú, centrali- } \\
\text { zált. }\end{array}$ \\
\hline
\end{tabular}


ben a TOP végrehajtását szabályozó megyei ITP kizárólag tematikus célokat tartalmaz, ráadásul a megyei jogú város és a megye többi részének kettéválasztása a funkcionális térségi megközelítés hiányát mutatja. Így az alkalmazott place-based kritériumrendszer első két szempontját illetően több vonatkozásban inkább fejlödésről, de legalábbis állandóságról beszélhetünk.

A harmadik vizsgált szempont, az intézményrendszer tekintetében azonban a kép felemás. Mind a 2007-es, mind a 2014-es időszak jelentős változást hozott a korábbihoz képest. Bár a megyei intézményrendszer hiányosságait már a 2003-as program felismerte, azok megoldására a megyei szintnek, a regionális szint elötérbe kerüléséből fakadóan, nem volt lehetősége. A fejlesztéspolitika regionális fókuszúvá válása együtt járt egy, a programvégrehajtáson és forráselosztáson túlmutató proaktív regionális intézményrendszer kialakításával, a helyi-térségi projektvégrehajtó kapacitások továbbra is hiányosak voltak, és erősen támaszkodtak a központi szervekre. A „visszamegyésítést” követő megyei intézményrendszer azonban - a hatáskörök csökkenése következtében, és a nem pontosan értelmezett területfejlesztési szerepből fakadóan - kevésbé tudott megerősödni. A koordinációs szerephez illeszkedő - a korábbi regionális fejlesztési ügynökségekhez hasonló - operatív projektgeneráló és -végrehajtó szerep kialakítása volt a cél. A megyei önkormányzat kapacitásainak zömét a TOP által finanszírozott projektek menedzsmentje foglalja le, saját megvalósítású projektjeinek köre, érdemi hatáskör híján, igencsak szűk. A TOP-on túlmutató témák vonatkozásában a megye továbbra is a helyi szinttől, illetve központi intézményrendszerektől függ. Összességében elmondható, hogy a három vizsgált dimenzió közül az intézményi kapacitások terén egyfelől ciklikusságot figyelhetünk meg, másfelől a meglévő intézményi hiátusok fennmaradásának vagyunk szemtanúi. A területi alapú fejlesztéspolitika intézményi dimenziójában az uniós csatlakozás óta nem történt előrelépés, sőt, a regionális fejlesztési ügynökségek programvégrehajtáson túlmutató szakértői tevékenysége, illetve nemzetközi kapcsolatrendszerének eltünése okán inkább visszalépésről beszélhetünk. A területalapú megközelítést, illetve a területi kohéziót gyengítő további körülmény, hogy elmarad az ITI alkalmazása, az ITP esetében nem érvényesül a funkcionális térségi szemlélet, illetve a CLLD mint eszköz alkalmazását a megyei jogú városokra korlátozzák.

A magyarországi területfejlesztési politika területi fókuszának erősítése érdekében, a Barca által meghatározott szempontoknak megfelelően, mindenképpen szükséges a részvételre vonatkozó szabályozás következetes alkalmazása, a minél szélesebb körű bevonás elősegítése, akár kötelező jogi eszközökkel is. A területi tudás megőrzését illetően nagyon fontos lenne, hogy a területfejlesztéssel foglalkozó koordinatív szerv továbbra is képes legyen belső munkában, saját tudásra építve, helyi szakértők bevonása mellett, területi célok megfogalmazásával végezni a tervezési folyamatot. Az intézményi kapacitás- és kompetenciahiányok kezelése érdekében pedig elengedhetetlen a megyei önkormányzatok, illetve a térségi végrehajtó szervezetek (kisvárosi vonzáskörzetek, járás) megerősítése, a 
program- és projektvégrehajtáson túlmutató szakértői háttér kialakítása, az integrált területi gondolkodás alkalmazása, a saját végrehajtású projektek számának növelése, valamint a térségi összefogást igénylő fejlesztési kérdésekben a valódi koordinációs és katalizátorszerephez szükséges kompetenciák, döntési jogosítványok kialakítása.

\section{Jegyzet}

1 A CLLD mint eszköz megjelenik ugyanakkor a vidékfejlesztési programokban, azonban erre jelen tanulmányban nem térek ki.

\section{Köszönetnyilvánítás}

A tanulmány az 132294. számú „Kormányzati kihívások periférikus térségekben” című projekt keretében, a Nemzeti Kutatási Fejlesztési és Innovációs Alapból biztosított támogatással, a K-19 pályázati program finanszírozásában valósult meg.

\section{Irodalom}

Bajmócy Z., Gébert J., Málovics Gy., Juhász J., Méreiné Berki B., Elekes Z., Páli-Dombi J. (2017): Részvétel vagy kizárás? A hazai városfejlesztés értékelése a folyamatok aspektusából. In: Bajmócy Z., Gébert J., Málovics Gy. (szerk.): Helyi gazdaságfejlesztés a képességszemélet alapján. JATEPress, Szeged, 97-134.

Barta Gy. (2009): Integrált városfejlesztési stratégia: a városfejlesztés megújítása. Tér és Társadalom, 3., 1-12. https://doi.org/10.17649/TET.23.3.1253

Barca, F. (2009): An Agenda for a Reformed Cohesion Policy - A place-based approach to meeting European Union challenges and expectations. Independent report prepared at the request of Danuta Hübner, Commissioner for Regional Policy http://ec.europa.eu/regional_policy/archive/policy/future/pdf/report_barca_v0306.pdf (Letöltés: 2018. 07. 05.)

Beer, A., McKenize, F., Blažek, J, Sotarauta, M., Ayres, S. (2020): Every place matters: towards effective place-based policy. Regional Studies Impact Books, Regional Studies Association, Abingdon

Davoudi, S. (2005): Understanding Territorial Cohesion. Planning, Practice \& Research, 4., 433-441. https://doi.org/10.1080/02697450600767926

Faludi, A. (2013): Territorial Cohesion and Subsidiarity under the European Union Treaties: A Critique of the 'Territorialism' Underlying. Regional Studies, 9., 1594-1606. https://doi.org/10.1080/00343404. 2012.657170

Fodor Á., Kálmán Sz., Lovász Gy., Németh Á., Wächter B. (2003): Partnerség figyelembe vétele a területfejlesztésben, különös tekintettel a civil szervezetekre. VÁTI Stratégiai Tervező Iroda http://www.terport.hu/webfm_send/298 (letöltés: 2021.06.24.)

Hooghe, L., Marks, G. (2003): Unravelling the Central State, but How? Types of Multilevel Governance. American Political Science Review, 2., 233-243. https://doi.org/10.1017/S0003055403000649

Janin Rivolin, U. (2010): EU territorial governance: learning from institutional progress. European Journal of Spatial Development https://www.researchgate.net/publication/241186002_EU_territorial_governance_Learning_from_institutional_progress (Letöltés: 2020. 05. 07.) 
Józsa V. (2018): Quo vadis regionalizmus? Egy eszme- és értékrendszer tovább élése a szakemberek közvetítésével. Tér és Társadalom, 3., 96-112. https://doi.org/10.17649/TET.32.3.3064

Keating, M. (1998): The New Regionalism in Western Europe: Territorial Restructuring of Political Change. Edward Elgar

Kovács K. (2013): Területi, társadalmi hátrányok és beavatkozási politikák. In: Kovács K., Váradi M.M. (szerk.): Hátrányban Vidéken. Argumentum, 25-54.

Manzella, G. P., Mendez, C. (2009): The turning points of EU Cohesion policy. http://ec.europa.eu/regional_policy/archive/policy/future/pdf/8_manzella_final-formatted.pdf (Letöltés: 2018. 07. 02.)

Márton Gy. (2004): Az Első Magyar Nemzeti Fejlesztési Terv tervezési folyamatának tapasztalatai regionális szemszögből. Falu Város Régió, 9., 32-45.

Márton Gy. (2009): Gondolatok a hazai decentralizált fejlesztési források felhasználásának megújításáról. Falu Város Régió, 3., 23-27.

Pálné Kovács, I. (2009): Europeanisation of Territorial Governance in Three Eastern/Central European Countries. Halduskultuur, 10., 40-57.

Pálné Kovács I., Mezei C. (2016): Regionális politikai és területi kormányzási ciklusok Közép- és Kelet-Európában. Tér és Társadalom, 4., 54-70. https://doi.org/10.17649/TET.30.4.2810

Scott, J. W. (2013): Territorial Cohesion, Cross-border Co-operation and the EU's Political Identity: A Brief Observation. In: Pálné Kovács, I., Scott, J., Gál, Z. (eds.): Territorial Cohesion in Europe - For the 70th anniversary of the Transdanubian Research Institute. Institute for Regional Studies, Centre for Economic and Regional Studies, Hungarian Academy of Sciences, Pécs, 73-84.

Simó B. (2019): A magyar regionális fejlesztési ügynökségek és müködési környezetük. Doktori értekezés. Pécsi Tudományegyetem Közgazdaságtudományi Kar, Regionális Politika és Gazdaságtan Doktori Iskola, Pécs, Budapest

Stead, D. (2014): The Rise of Territorial Governance in European Policy. European Planning Studies, 7., 1368-1383. https://doi.org/10.1080/09654313.2013.786684

\section{Felhasznált források}

BMÖ (2013): Baranya Megyei Területfejlesztési Koncepció Helyzetelemző munkarész http://www.terport.hu/webfm_send/4171 (Letöltés: 2020. 05. 06.).

BMÖ (2014a): Baranya Megyei Területfejlesztési Koncepció Javaslattételi fázis https://docplayer.hu/ 11934816-Baranya-megyei-teruletfejlesztesi-koncepcio.html (Letöltés: 2020. 09. 07.).

BMÖ (2014b): Baranyai Megyei Területfejlesztési Program Stratégiai és Operatív Program https:// docplayer.hu/3113020-Baranya-megyei-teruletfejlesztesi-program.html (Letöltés: 2020.09. 07.)

BMÖ (2020): Baranya Megye Integrált Területi Programja http://www.baranya.hu/dokumentum/808 (Letöltés: 2020. 05. 06.)

BMTT (2003): Baranya Megye Területfejlesztési Programja Baranya Megyei Területfejlesztési Tanács http:// www.terport.hu/webfm_send/700 (Letöltés: 2020. 05 06.).

EC (2008): Green Paper on Territorial Cohesion - Turning territorial diversity into strength. Commission of the European Communities. Brussels. http://ec.europa.eu/regional_policy/archive/consultation/terco/paper_terco_en.pdf (Letöltés: 2018. 07. 02.)

EC (2009): Territorial cohesion: unleashing the territorial potential. Background Document to the Conference on Cohesion Policy and Territorial Development: Make Use of the Territorial Potential!, 10-11 December 2009, Kiruna, Sweden http://www.esponontheroad.eu/dane/web_espon_library_files/697/zl_kiruna_20091211.pdf (Letöltés: 2020. 05. 07.)

EC (2018): Proposal for a Regulation of the European Parliament and of the Council on the European Regional Development Fund and the Cohesion Fund. $\operatorname{COM}(2018) 372$ final https://eur-lex.europa.eu/legalcontent/EN/TXT/?uri=COM\%3A2018\%3A372\%3AFIN (Letöltés: 2020. 01. 09.)

ESDP (1999): ESDP European Spatial Development Perspective - Towards Balanced and Sustainable Development of the Territory of the European Union. Agreed at the Informal Council of Ministers 
responsible for Spatial Planning in Potsdam, May 1999. Published by the European Commission (Letöltés: 2018.07.02.)

EU2007.de (2007): Leipzig Charter on Sustainable European Cities. Final draft (02 May 2007). https:// ec.europa.eu/regional_policy/archive/themes/urban/leipzig_charter.pdf (Letöltés: 2020. 07. 16.)

Kormány (2007): Dél-dunántúli operatív program 2007-2013. A Magyar Köztársaság Kormánya http:// www.terport.hu/webfm_send/318 (Letöltés: 2020.07.07.)

Lechner Tudásközpont (2017): TOP CLLD Müködési Kézikönyv helyi akciócsoportok számára. https:// www.palyazat.gov.hu/download.php?objectId=1091418 (Letöltés: 2021. 06. 26.)

Ministry of Regional Development (2013): Place-based. Territorially sensitive and integrated approach. https://www.researchgate.net/publication/330293378_Place_based_Territorially_Sensitive_and_Integrated_Approach/link/5c37c22b92851c22a36b27a3/download (Letöltés: 2020. 05. 06.)

NGM (2015): Útmutató a megyék integrált területi programjainak kidolgozásához és megvalósitásához. 2.0 verzió. Nemzetgazdasági Minisztérium http://www.vpmegye.hu/kgy2015/20150226/ITP_utmutato.pdf (Letöltés: 2020. 10. 23.)

Pécs MJV (2014): Pécs MJV városfejlesztési koncepció 2014-2030. https://www.pvfzrt.hu/hu/tanulmany/ 15/pecs-mjv-varosfejlesztesi-koncepcio-2014-2030 (Letöltés: 2020. 07. 20.)

Regulation (1999): Council Regulation (EC) No 1260/1999 of 21 June 1999 laying down general provisions on the Structural Fund https://eur-lex.europa.eu/legal-content/EN/TXT/PDF/?uri=CELEX31999R 1260\&from=EN (Letöltés: 2020.07.20.)

Regulation (2006): Council Regulation (EC) No 1083/2006 of 11 July 2006 laying down general provisions on the European Regional Development Fund, the European Social Fund and the Cohesion Fund and repealing Regulation (EC) No 1260/1999. https://eur-lex.europa.eu/legal-content/EN/TXT/ PDF/?uri=CELEX:32006R1083\&from=EN (Letöltés: 2019.01.31.)

Regulation (2013): Regulation (EU) No 1303/2013 of the European Parliament and of the Council of 17 December 2013 laying down common provisions on the European Regional Development Fund, the European Social Fund, the Cohesion Fund, the European Agricultural Fund for Rural Development and the European Maritime and Fisheries Fund and laying down general provisions on the European Regional Development Fund, the European Social Fund, the Cohesion Fund and the European Maritime and Fisheries Fund and repealing Council Regulation (EC) No 1083/2006. https://eur-lex.europa.eu/ legal-content/EN/TXT/PDF/?uri=CELEX:32013R1303\&from=EN (Letöltés: 2019.09.12.) 